\title{
40 Tahun Penyelidikan Fakulti Pengajian Islam Universiti Kebangsaan Malaysia
}

\author{
40 Years of Research in the Faculty of Islamic Studies \\ Universiti Kebangsaan Malaysia
}

\author{
AHMAD SUNAWARI LONG* \& ZAIZUL AB. RAHMAN1
}

\begin{abstract}
Since its establishment on May 18, 1970, various researches on Islam and Muslim communities were conducted by researchers of Faculty of Islamic Studies. Various grants are channelled to the researchers, including IRPA grant, (The Intensification of Research in Priority Areas), FRGS Grant (Fundamental Research Grant Scheme), Grant from government agencies such as the Department of Islamic Development Malaysia (JAKIM) and the Ministry of Education, University Research Grant (GUP), Action/Strategic Research Grant, Arus Perdana Grant, Laluan Pantas Grant and Incentive Grant Funds. Since its establishment, it is estimated that RM3 million grant has been granted to the researchers. Although there are various grants and the number of extensive researches, the result of the researches have not been published in any high impact journals such as Scopus and ISI (Institute for Scientific Information). The change of qualitative research to quantitative research that emphasizes the quantitative elements and its impact to the country should be intensified in the Faculty of Islamic Studies.
\end{abstract}

Keywords: research, Faculty of Islamic Studies.

Fakulti Pengajian Islam telah ditubuhkan pada 18 Mei 1970 bermula dengan dua jabatan terawal iaitu Jabatan Syariah dan Jabatan Usuluddin dan Falsafah serta Unit Bahasa Arab. Pada tahun 1974, unit tersebut telah dinaiktaraf kepada Jabatan Pengajian Arab dan Tamadun Islam. Lima tahun kemudian, Jabatan Pengajian Dakwah dan Kepimpinan telah ditubuhkan sebagai pecahan Jabatan Usuluddin dan Falsafah. Pada tahun 1979, daripada Jabatan Syariah tertubuh Jabatan Pengajian al-Quran dan al-Sunnah. Pada tiga dekad terawal penubuhannya, penyelidikan di Fakulti Pengajian Islam banyak tertumpu kepada isu-isu semasa yang berlaku dalam masyarakat dengan bersumberkan geran dalaman sekitar RM1000.00.

Sejarah terawal penyelidikan di Fakulti Pengajian Islam bermula dengan kajian Abdul Jalil Hasan mengenai Syeikh Muhammad Arshad bin Abdullah al-Banjari pada tahun 1971 yang diselesaikannnya pada tahun 1972 (Laporan Tahunan Pertama 1970-1971: 17; $2^{\text {nd }}$ Annual Report 1971-1972: 56). Dalam Audit Akademik Fakulti Pengajian Islam (Fakulti Pengajian Islam 1998: 74), penyelidikan di Fakulti Pengajian Islam dikategorikan kepada dua bentuk iaitu kajian yang mendapat geran daripada luar (seperti Kementerian

\footnotetext{
${ }^{1}$ Ahmad Sunawari Long*(corresponding author), Ph.D., Associate Professor at Department of Theology and Philosophy, Faculty of Islamic Studies, Universiti Kebangsaan Malaysia, 43600 BANGI, Selangor, Malaysia, email: aslong@ukm.edu.my; Zaizul Ab. Rahman, Ph.D., Senior Lecturer at Department of Theology and Philosophy, Faculty of Islamic Studies, Universiti Kebangsaan Malaysia, 43600 BANGI, Selangor, Malaysia, email: zaizul@ukm.edu.my.
} 
Pendidikan Malaysia, Majlis Agama Islam Terengganu, Pemegang Amanah Kolej Islam Malaya dan Jabatan Kemajuan Islam Malaysia) dan daripada sumber kewangan Universiti (seperti geran jangka pendek dan Arus Perdana). Namun terdapat kesukaran dalam mengesani penyelidik dan geran yang telah diperolehi para penyelidik Fakulti Pengajian Islam kerana ketiadaan satu sistem data base mengenai penyelidikan atau sistem berpusat laporan penyelidikan. Berikut senarai beberapa penyelidikan menggunakan dana agensi luar yang dapat dikesan sepanjang tempoh 30 tahun awal penubuhannya. Jadual berikut menunjukkan $70 \%$ daripada dana diperolehi daripada Kementerian Pendidikan Malaysia sepertimana Jadual 1 di bawah:

\begin{tabular}{|c|l|l|}
\hline Tahun & \multicolumn{1}{|c|}{ Tajuk Penyelidikan } & \multicolumn{1}{|c|}{ Agensi Penyalur Dana } \\
\hline 1989 & $\begin{array}{l}\text { Penempatan dan Pembinaan Rumah Warga Kanan Tak } \\
\text { Berwaris }\end{array}$ & $\begin{array}{l}\text { Bahagian Hal Ehwal Islam, } \\
\text { Jabatan Perdana Menteri }\end{array}$ \\
\hline 1994 & $\begin{array}{l}\text { Keberkesanan Perlaksanaan Aliran Agama di Sekolah } \\
\text { Menengah Biasa }\end{array}$ & $\begin{array}{l}\text { Kementerian Pendidikan } \\
\text { Malaysia }\end{array}$ \\
\hline 1996 & $\begin{array}{l}\text { Penyertaan Pelajar dan Guru dalam Kegiatan Ko } \\
\text { Kurikulum Agama Sekolah Menengah Kebangsaan }\end{array}$ & $\begin{array}{l}\text { Kementerian Pendidikan } \\
\text { Malaysia }\end{array}$ \\
\hline 1996 & $\begin{array}{l}\text { Pendidikan Islam di Sekolah Kebangsaan dan Sekolah } \\
\text { Rendah Kebangsaan }\end{array}$ & $\begin{array}{l}\text { Kementerian Pendidikan } \\
\text { Malaysia }\end{array}$ \\
\hline 1996 & $\begin{array}{l}\text { Keberkesanan Pendidikan Islam di Sekolah Vokasional } \\
\text { Malaysia }\end{array}$ & $\begin{array}{l}\text { Kementerian Pendidikan } \\
\text { Malaysia }\end{array}$ \\
\hline 1997 & $\begin{array}{l}\text { Penyertaan Pelajar dan Guru dalam Kegiatan Ko } \\
\text { Kurikulum Agama Sekolah Menengah Kebangsaan } \\
\text { Kerohanian Tilawah al-Quran Pelajar Sekolah Rendah } \\
\text { Malaysia Barat }\end{array}$ & $\begin{array}{l}\text { Kementerian Pendidikan } \\
\text { Malaysia }\end{array}$ \\
\hline 1997 & $\begin{array}{l}\text { Kemgetahuan Sikap dan Penerian Pendidikan } \\
\text { terhadap Aktiviti Dakwah Jabatan Hal Ehwal Agama } \\
\text { Terengganu dan Yayasan Islam Terengganu }\end{array}$ \\
\hline 1998 & $\begin{array}{l}\text { Sejarah Pendidikan Tinggi Islam Malaysia } \\
\text { Majlis Agama Islam Terengganu }\end{array}$ \\
\hline 1998 & $\begin{array}{l}\text { Perkembangan Dakwah Keluar di Malaysia } \\
\text { Pemegang Amanah Kolej Islam } \\
\text { Malaya }\end{array}$ \\
\hline
\end{tabular}

Jadual 1: Penyelidikan Fakulti Pengajian Islam Bersumber Dana Luar UKM dalam Tempoh 30 Tahun Penubuhannya

Kerancakan penyelidikan di Fakulti Pengajian Islam dapat dilihat apabila Universiti Kebangsaan Malaysia dinobatkan sebagai Universiti Penyelidikan pada tahun 2006. Dengan pengiktirafan ini, para penyelidik Fakulti tersebut mula menunjukkan kesungguhan menjalankan penyelidikan sebagaimana ditunjukkan dengan peruntukan Geran Universiti Penyelidikan (GUP) berjumlah RM2,837,206.00 bagi membiayai 31 projek penyelidikan. Dalam tempoh empat dekad, para penyelidik Fakulti Pengajian Islam memperolehi geran penyelidikan daripada pelbagai sumber yang dikategorikan kepada geran IRPA (The Intensification of Research in Priority Areas), FRGS (Fundamental Research Grant Scheme), Agensi Luar, Geran Universiti Penyelidikan (GUP), Arus Perdana, Geran Penyelidikan Tindakan UKM, Geran Laluan Pantas dan Geran Dana Galakan. Geran Laluan Pantas disediakan oleh pihak Fakulti pada tahun 2005 kepada penyelidik muda yang belum menceburi bidang penyelidikan atau kepada penyelidik yang baru menyiapkan pengajian peringkat doktor falsafah. 


\section{Geran IRPA}

IRPA (The Intensification of Research in Priority Areas) telah diperkenalkan oleh Kementerian Sains Teknologi dan Inovasi (MOSTI) pada tahun 1988. Geran IRPA dikelolakan oleh MASTIC (Malaysian Science and Technology Infornmation Centre) dengan pemokusan kepada aktiviti penyelidikan dan pembangunan (research and development R\&D) dalam bidang yang boleh mempertingkatkan kedudukan sosio ekonomi. Pemberian dana ini berdasarkan kepada empat prinsip yang telah digariskan oleh National Council for Scientific Research and Development (MPKSN) iaitu:

- Menyediakan dana kepada projek yang mempunyai keutamaan nasional dan mampu pasaran.

- Menyediakan dana untuk projek yang diperlukan oleh industri Malaysia.

- Menggalakkan usaha kolaborasi antara institusi-institusi penyelidikan.

- Meningkatkan hubungan R\&D antara sektor kerajaan dan swasta (Ministry of Science, Technology and the Environment t.th.: 3).

Walau bagaimanapun IRPA memberi kelonggaran kepada bidang-bidang yang boleh meningkatkan ilmu pengetahuan jangka panjang rakyat demi meningkatkan kapasiti pembangunan K-ekonomi. Di Fakulti Pengajian Islam, bidang muamalat dan ekonomi Islam menjadi tujahan kepada Jabatan Syariah di Fakulti Pengajian Islam yang kelihatan lebih hampir kepada K-ekonomi tersebut, tetapi hanya satu penyelidikan yang diketuai oleh Hailani Muji Tahir yang berjaya memperolehi geran berkenaan. Tiga penyelidikan IRPA lain dibolot oleh para penyelidik di Jabatan Usuluddin dan Falsafah. Keseluruhannya, dalam tempoh kewujudan geran IRPA selama 18 tahun (1988-2006) penyelidik Fakulti Pengajian Islam hanya berjaya mengumpul geran kurang daripada RM500,000.00 Projek-projek tersebut seperti pada jadual 2 berikut:

\begin{tabular}{|c|l|l|c|c|}
\hline Bil. & \multicolumn{1}{|c|}{ Tajuk } & Ketua Penyelidik & Tahun & RM \\
\hline 1. & $\begin{array}{l}\text { Sumber Zakat, Agihan dan Pengaplikasiannya } \\
\text { kepada Individu dan Syarikat }\end{array}$ & Hailani Muji Tahir & 2004 & $186,000.00$ \\
\hline 2. & $\begin{array}{l}\text { Sistem Pakar Khidmat Nasihat Kekeluargaan } \\
\text { Islam: Pendekatan dan Implementasi }\end{array}$ & Jawiah Dakir & 2004 & $128,000.00$ \\
\hline 3. & $\begin{array}{l}\text { Agama sebagai Asas Kefahaman Toleransi: Satu } \\
\text { Kajian di Kalangan Pelajar-Pelajar IPTA }\end{array}$ & $\begin{array}{l}\text { Muda@Ismail } \\
\text { Ab. Rahman }\end{array}$ & 2005 & $87,500.00$ \\
\hline 4. & $\begin{array}{l}\text { Kajian Keberkesanan Program Pemulihan Dadah } \\
\text { ke Arah Penyediaan Modul Pendidikan Islam di } \\
\text { Pusat-pusat Serenti }\end{array}$ & Zakaria Stapa & 2005 & $86,472.00$ \\
\hline \multicolumn{3}{|l|}{ Jumlah } & & $487,972.00$ \\
\hline
\end{tabular}

Jadual 2: Dana IRPA yang Diperolehi oleh Penyelidik Fakulti Pengajian Islam

\section{Geran FRGS}

Penyelidikan fundamental merupakan satu penerokaan idea-idea, konsep atau teori baru yang menjadi tunjang kepada penemuan baru, perkembangan ilmu dan ciptaan yang canggih dan terkini. Sehubungan itu, di bawah Rancangan Malaysia Ke-Sembilan (RMK-9), Kementerian Pengajian Tinggi (KPT) telah memperuntukan sebanyak RM200 juta bagi membiayai projek-projek penyelidikan fundamental di IPTA. Pihak Kementerian telah 
membuka permohonan FRGS buat pertama kalinya pada tahun 2006. Keputusan penyelidikan fundamental IPTA ini ditentukan oleh sekumpulan Jawatankuasa Penilaian FRGS yang dianggotai oleh pakar-pakar dari IPTA. Secara amnya, projek-projek penyelidikan fundamental ini telah dikelaskan kepada enam bidang iaitu Sains Tulen, Sains Gunaan, Sains Sosial dan Sastera, Sains Perubatan, Teknologi dan Kejuruteraan serta Natural Science and National Heritage. Bidang tujahan dan kepakaran di Fakulti Pengajian Islam diletakkan di bawah kategori Sains Sosial dan Sastera. Terdapat tiga bentuk dana penyelidikan yang diberi di bawah FRGS iaitu:

- Dana penyelidikan bagi projek-projek yang dipohon oleh penyelidik melalui pengurusan Penyelidikan di IPTA masing-masing.

- Dana penyelidikan bagi projek -projek yang dikenalpasti oleh pihak jawatankuasa Geran Penyelidikan Fundamental secara top down.

- Dana galakan kepada IPTA yang terpilih (http://jpt.mohe.gov.my/menupenyelidik. php.dg).

Proses penilaian dan perakuan bagi setiap permohonan projek penyelidikan di Fakulti Pengajian Islam melalui beberapa peringkat proses saringan bermula dengan saringan pada peringkat Jawatankuasa Penyelidikan peringkat Jabatan, diikuti oleh Jawatankuasa Penyelidikan Fakulti dan seterusnya pada peringkat Pusat Pengurusan Penyelidikan (PPP). Berikut adalah senarai penyelidikan yang berjaya memprolehi geran FRGS sehingga akhir tahun 2009 sepertimana dalam Jadual 3 di bawah:

\begin{tabular}{|c|c|c|c|c|}
\hline Bil. & Tajuk & Ketua Projek & Tahun & $\mathbf{R M}$ \\
\hline 1. & $\begin{array}{l}\text { Kebangkitan Semula Islam dan Impaknya } \\
\text { Terhadap Pemikiran dan Penghayatan Islam } \\
\text { Golongan Kelas Menengah Muslim Malaysia: } \\
\text { Kajian Kes di Lembah Klang }\end{array}$ & $\begin{array}{l}\text { Ahmad Sunawari } \\
\text { Long }\end{array}$ & 2006 & $60,000.00$ \\
\hline 2. & $\begin{array}{l}\text { Salah Tanggapan terhadap Hadith-hadith yang } \\
\text { Masyhur dalam Masyarakat Melayu: Kajian } \\
\text { Sumber dan Penilaian Semula }\end{array}$ & Jawia & 2006 & $60,000.00$ \\
\hline 3. & Aliran Islam Liberal di Malaysia dan Indonesia & Moh & 006 & 65, \\
\hline 4. & $\begin{array}{l}\text { Citra Dakwah dalam Novel Melayu Pilihan: } \\
\text { Kajian Pandangan dan Kecenderungan Pembaca } \\
\text { Remaja }\end{array}$ & Rugayah Tibek & 2006 & $60,000.00$ \\
\hline 5. & $\begin{array}{l}\text { Kajian Penyertaan Agama, Konsep Kendiri dan } \\
\text { Keperluan Kaunseling Warga Tua Rumah Seri } \\
\text { Kenangan di Malaysia }\end{array}$ & Zaina & 2006 & $60,000.00$ \\
\hline 6. & $\begin{array}{l}\text { Pengurusan dan Pembangunan Hartanah Wakaf } \\
\text { Majlis Agama Islam Negeri-Negeri di } \\
\text { Semenanjung Malaysia }\end{array}$ & $\begin{array}{l}\text { Siti Zalikah Md } \\
\text { Nor }\end{array}$ & 2006 & $30,000.00$ \\
\hline 7. & $\begin{array}{l}\text { Perlaksanaan Program Latihan Khidmat Negara } \\
\text { (PLKN): Kajian Pembentukan Modul Kerohanian }\end{array}$ & Fariza Md. Sham & 2006 & $28,000.00$ \\
\hline 8. & $\begin{array}{l}\text { Faktor-Faktor Kemunculan Terrorisme di Dunia } \\
\text { Islam dan Pengaruhnya ke Atas Masyarakat } \\
\text { Islam Malaysia }\end{array}$ & Ismail Bakar & 2006 & $26,000.00$ \\
\hline 9. & $\begin{array}{l}\text { Pembangunan Metodologi Dakwah Masyarakat } \\
\text { Orang Asli Malaysia }\end{array}$ & $\begin{array}{l}\text { Badlihisham Mohd } \\
\text { Nasir }\end{array}$ & 2006 & $26,000.00$ \\
\hline 10. & $\begin{array}{l}\text { Komunikasi di Institusi Masjid ke } \text { Arah } \\
\text { Menrealisasikan Islam Hadhari Malaysia }\end{array}$ & $\begin{array}{l}\text { Zulkiple Abd. } \\
\text { Ghani }\end{array}$ & 2006 & $26,000.00$ \\
\hline 11. & Toleransi Beragama di Kalangan Pelajar-pelajar & Jaffary Awang & 2006 & $26,000.00$ \\
\hline
\end{tabular}


Vol.1: (June) 2012

\begin{tabular}{|c|c|c|c|c|}
\hline & Institusi Pengajian Tinggi Swasta di Malaysia & & & \\
\hline 12. & Sikap Orang Melayu terhadap Prinsip Kausaliti & $\begin{array}{l}\text { Ibrahim Abu } \\
\text { Bakar }\end{array}$ & 2007 & $24,758.00$ \\
\hline 13. & $\begin{array}{l}\text { Sejarah Ketenteraan Islam sebagai satu Disiplin } \\
\text { Ilmu: Modul Pembelajaran bagi Universiti } \\
\text { Pertahanan Malaysia (UPNM) }\end{array}$ & $\begin{array}{l}\text { Ezzad Azrai } \\
\text { Jamsari }\end{array}$ & 2007 & $60,000.00$ \\
\hline 14. & $\begin{array}{l}\text { Paradigma Pemikiran Bukan Melayu Terhadap } \\
\text { Kepimpinan Melayu di Malaysia }\end{array}$ & $\begin{array}{l}\text { Abdull Rahman } \\
\text { Mahmood }\end{array}$ & 2009 & $42,400.00$ \\
\hline 15. & $\begin{array}{l}\text { Reaksi Institusi Islam Terhadap Fahaman Islam } \\
\text { Leberal di Malaysia: Kajian Terhadap Strategi } \\
\text { dan Pendekatan }\end{array}$ & $\begin{array}{l}\text { Latifah Abdul } \\
\text { Majid }\end{array}$ & 2009 & $40,000.00$ \\
\hline 16. & $\begin{array}{l}\text { Konsep Lindung Nilai (Hedging) Islam dalam } \\
\text { Sistem Kewangan }\end{array}$ & Mat Noor Mat Zain & 2009 & $38,400.00$ \\
\hline 17. & $\begin{array}{l}\text { Histeria: Punca dan Kaedah Menangani Menurut } \\
\text { Perspektif Psikologi Islam }\end{array}$ & Fariza Md. Sham & 2009 & $50,000.00$ \\
\hline 18. & $\begin{array}{l}\text { Inovasi dan Latihan Pengurusan Pengajaran } \\
\text { Bahasa Arab Berasaskan Komponen Motivasi }\end{array}$ & Kaseh Abu bakar & 2009 & $30,000.00$ \\
\hline 19. & $\begin{array}{l}\text { Pembentukan Dasar Negara Berasaskan Maqasid } \\
\text { Syariah }\end{array}$ & $\begin{array}{l}\text { Amir Husin Mohd } \\
\text { Nor }\end{array}$ & 2009 & $50,000.00$ \\
\hline 20. & $\begin{array}{l}\text { Wasiat Sebagai Mekanisme Perancangan Harta: } \\
\text { Kajian di Selangor, Negeri Sembilan dan Melaka }\end{array}$ & $\begin{array}{l}\text { Ahmad Ridzuan } \\
\text { Awang }\end{array}$ & 2009 & $30,000.00$ \\
\hline 21. & Penentuan Hukum Bioteknologi Pemakanan & $\begin{array}{l}\text { Abdul Basir } \\
\text { Mohamad }\end{array}$ & 2009 & $30,000.00$ \\
\hline \multicolumn{4}{|c|}{ Jumlah } & $863,258.00$ \\
\hline
\end{tabular}

Jadual 3: Dana FRGS yang Diperolehi oleh Penyelidik Fakulti Pengajian Islam

Data di atas menunjukkan pada tahun 2006, penyelidikan di Fakulti Pengajian Islam telah melakukan permulaan yang baik apabila para penyelidiknya telah berjaya memperolehi sejumlah 11 projek yang bernilai RM467,500.00. Walau bagaimanapun, pada tahun 2007 hanya terdapat 2 projek yang diperolehi dengan nilai RM85,758.00. Malangnya pada tahun 2008 tiada satu projek FRGS yang berjaya diperolehi oleh mana-mana para penyelidik. Namun pada tahun 2009, jumlah penyelidikan FRGS kembali meningkat apabila 8 projek penyelidikan bernilai RM310,000.00 diperolehi. Pada tahun tersebut, 4 projek diketuai oleh para penyelidik Jabatan Syariah. Semenjak Pengenalan FRGS paada tahun 2006, penyelidik Jabatan Syariah memperolehi 5 projek penyelidikan berjumlah RM178 000.00, Jabatan Usuluddin dan Falsafah (6 projek = RM278,658.00), Jabatan Pengajian Dakwah dan Kepimpinan (6 projek = RM250,000.00), Jabatan Pengajian Arab dan Tamadun Islam (3 projek =RM116 000.00) serta Jabatan Pengajian al-Quran dan al-Sunnah (1 projek = RM40,000.00). Senarai tersebut juga menunjukkan, hanya penyelidik Fariza Md. Sham pernah mengetuai 2 projek penyelidikan FRGS di Fakulti Pengajian Islam.

\section{Dana Agensi Luar}

Pelbagai agensi luar terlibat dalam penyediaan dana kepada para penyelidik Fakulti Pengajian Islam terutamanya daripada pihak Jabatan Kemajuan Islam Malaysia (JAKIM). Walau bagaimanapun Kementerian Pelajaran Malaysia menjadi institusi terawal yang pernah menyediakan dana kepada penyelidik Fakulti Pengajian Islam pada tahun 1989 seperti dijelaskan pada awal perbincangan. Seawal tahun 2000, dana luar adalah sangat terhad dalam pembiayaan penyelidikan di Fakulti seperti ditunjukkan dalam Jadual berikut 
Sepanjang empat dekad penubuhannya, keseluruhan dana agensi luar yang diperolehi melebihi setengah juta ringgit sebagaimana dalam Jadual 4 di bawah:

\begin{tabular}{|c|c|c|c|c|}
\hline Bil. & Tajuk & $\begin{array}{c}\text { Ketua } \\
\text { Penyelidik }\end{array}$ & Tahun dan Agensi & RM \\
\hline 1. & $\begin{array}{l}\text { Radical Religious Movement in } \\
\text { Japan }\end{array}$ & $\begin{array}{l}\text { Ibrahim Abu } \\
\text { Bakar }\end{array}$ & $\begin{array}{c}2000 \\
\text { Japan Society for } \\
\text { Promotion of Science }\end{array}$ & $20,000.00$ \\
\hline 2. & $\begin{array}{l}\text { Isu-isu Akidah } \text { Umat Islam } \\
\text { Malaysia }\end{array}$ & $\begin{array}{l}\text { Mohd Yusoff } \\
\text { Hussein }\end{array}$ & $\begin{array}{l}2000 \\
\text { Jab. Kemajuan Islam } \\
\text { Malaysia }\end{array}$ & $100,000.00$ \\
\hline 3. & $\begin{array}{lrr}\text { Kajian Hala Tuju } & \text { Pegawai- } \\
\text { Pegawai } & \text { Agama } & \text { dalam } \\
\text { Perkhidmatan Awam } & \end{array}$ & $\begin{array}{l}\text { Mohd Yusoff } \\
\text { Hussein }\end{array}$ & $\begin{array}{l}2001 \\
\begin{array}{l}\text { Jab. Kemajuan Islam } \\
\text { Malaysia }\end{array}\end{array}$ & $80,000.00$ \\
\hline 4. & $\begin{array}{l}\text { Kajian Keberkesanan Kelas } \\
\text { Pengajian Takmir Masjid/Surau } \\
\text { Semenanjung Malaysia }\end{array}$ & $\begin{array}{l}\text { Mohd Yusoff } \\
\text { Hussein }\end{array}$ & $\begin{array}{l}2002 \\
\begin{array}{l}\text { Jab. Kemajuan Islam } \\
\text { Malaysia }\end{array} \\
\end{array}$ & $100,000.00$ \\
\hline 5. & $\begin{array}{llr}\text { Projek } & \text { Penyelidikan } & \text { dan } \\
\text { Penulisan } & \text { Perbendaharaan } & \text { al- } \\
\text { Quran } & & \\
\end{array}$ & $\begin{array}{l}\text { Sulaiman } \\
\text { Ibrahim }\end{array}$ & $\begin{array}{l}\text { Majlis Agama Islam } \\
\text { Selangor-KUIS }\end{array}$ & $2,000.00$ \\
\hline 6. & $\begin{array}{l}\text { Kajian Pengaruh Black Metal } \\
\text { Terhadap Remaja Islam di } \\
\text { Seremban, Negeri Sembilan }\end{array}$ & $\begin{array}{l}\text { Mohd. Nasran } \\
\text { Mohamad }\end{array}$ & $\begin{array}{l}\text { Jab. Mufti Negeri } \\
\text { Sembilan }\end{array}$ & $50,020.00$ \\
\hline 7. & $\begin{array}{lll}\text { Pembangunan } & \text { Modul Sahsiah } \\
\text { Belia Malaysia } & & \\
\end{array}$ & Jawiah Dakir & $\begin{array}{c}2009 \\
\text { Kem. Belia dan Sukan }\end{array}$ & $220,000.00$ \\
\hline 8. & $\begin{array}{lcr}\text { Keberkesanan } & \text { Modul } & \text { Pengajian } \\
\text { Islam di } & \text { Pusat } & \text { Serenti } \\
\text { Semenanjung Malaysia } & \\
\end{array}$ & Zakaria Stapa & $\begin{array}{c}2009 \\
\text { Agensi Anti Dadah } \\
\text { Kebangsaan }\end{array}$ & $74,500.00$ \\
\hline 9. & $\begin{array}{l}\text { Kajian Keberkesanan } \\
\text { Pelaksanaan Modul Kursus } \\
\text { Pendekatan Islam Hadhari di } \\
\text { Kementeraian dan Agensi-Agensi } \\
\text { Kerajaan }\end{array}$ & $\begin{array}{l}\text { Ahmad } \\
\text { Sunawari Long }\end{array}$ & $\begin{array}{l}2010 \\
\text { Jab. Kemajuan Islam } \\
\text { Malaysia }\end{array}$ & $59,299.00$ \\
\hline \multicolumn{4}{|c|}{ Jumlah } & $507,819.00$ \\
\hline
\end{tabular}

Jadual 4: Dana Agensi Luar yang Diperolehi oleh Penyelidik Fakulti Pengajian Islam Sejak Tahun 2000

Hampir kesemua geran penyelidikan di atas bersumberkan agensi dalam negara terutama JAKIM kecuali geran Japan Society for Promotion of Science yang diperolehi oleh Ibrahim Abu Bakar pada tahun 2000. Penyelidikan pertama di Fakulti Pengajian Islam yang memperolehi geran luar negara ini menjalankan kajian tentang Radical Religious Movement in Japan di bawah program Invitation Fellowship Programs for Research In Japan.

\section{Geran GUP}

Dana di bawah Geran Universiti Penyelidikan telah merancakkan penyelidikan kalangan pensyarah Fakulti Pengajian Islam terutama kalangan pensyarah muda yang masih belum bertaraf professor madya atau profesor. Pada tahun 2009, enam tujahan (niche) telah dibentuk di Fakulti Pengajian Islam bagi melaksanakan dana-dana GUP. Pada prinsipnya tujahan-tujahan tersebut dibina berdasarkan jabatan yang terdapat di Fakulti tetapi lebih cenderung kepada pemecahan pengkhususan jabatan dengan penumpuan kepada 
perkongsian bidang yang boleh disatukan. Keenam-enam tujahan tersebut dikelompokkan di bawah Keagamaan dan Pemikiran Islam; Ilmu Wahyu dan Turath Islam; Dakwah, Kerohanian dan Pembangunan Insan; Perundangan Islam dan Muamalat; Islam dan Masyarakat Semasa, serta; Kebudayaan Arab dan Tamadun Islam. Tujahan-tujahan berkenaan berada di bawah bidang tujahan Pembangunan Insan dan Tamadun Islam di bawah niche area Jatidiri Kebangsaan, Negara Bangsa, Kepelbagaian Budaya dan Globalisasi. Berikut peruntukan geran berdasarkan kepada tujahan, tetapi tujahan Islam dan Masyarakat kemudiannya diletakkan di bawah pengurusan Institut Islam Hadhari sebagaimana dalam Jadual 5 di bawah:.

\begin{tabular}{|c|l|c|r|}
\hline Bil. & \multicolumn{1}{|c|}{ Tujahan } & Bilangan & Jumlah (RM) \\
\hline 1. & Keagamaan dan Pemikiran Islam & 4 & $560,000.00$ \\
\hline 2. & Ilmu Wahyu dan Turath Islam & 3 & $340,762.00$ \\
\hline 3. & Dakwah, Kerohanian dan Pembangunan Insan & 10 & $611,800.00$ \\
\hline 4. & Perundangan Islam dan Muamalat & 4 & $279,644.00$ \\
\hline 5. & Islam dan Masyarakat Semasa & 3 & $245,000.00$ \\
\hline 6. & Kebudayaan Arab dan Tamadun Islam & 7 & $680,000.00$ \\
\hline \multicolumn{2}{|c|}{ Jumlah Keseluruhan } & $2,837,206.00$ \\
\hline
\end{tabular}

Jadual 5: Peruntukan Dana GUP kepada Bidang Tujahan

Sebanyak 31 penyelidikan telah berjaya memperolehi dana GUP tersebut. Penyelidikan Survival Minoriti Etnik Melayu Muslim: Kajian Etnografi terhadap Amalan Keagamaan dan Akidah Islam di bawah tujahan Keagamaan dan Pemikirian memperolehi peruntukan terbesar sebanyak RM370,000.00, manakala projek penyelidikan Jama ìyyat alMashari' al-Khairiyyah al-Islamiyyah: Kajian Metode Dakwah Sufi dan Hubungannya dengan Institut Dakwah Islamiah di Malaysia mendapat dana terendah sebanyak RM21,800.00. Majoriti atau 7 penyelidik memperolehi Geran Universiti Penyelidikan sebanyak RM80,000.00. Tujahan Dakwah, Kerohanian dan Pembangunan Insan berjaya memperolehi 10 penyelidikan, manakala kumpulan tujahan Kebudayaan Arab dan Tamadun Islam mengumpul dana paling banyak terkumpul sejumlah RM680,000.00.

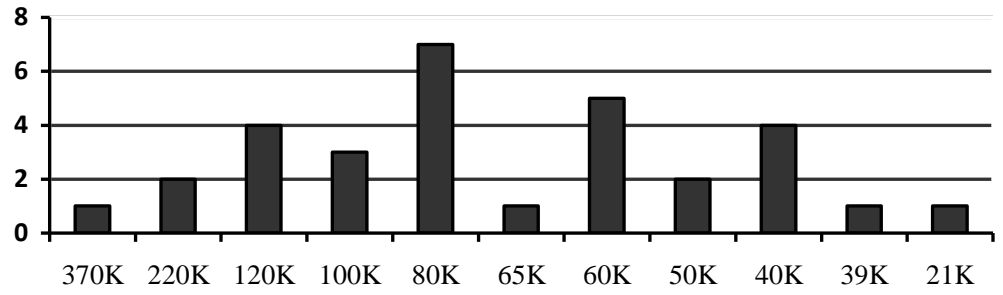

\section{Geran Arus Perdana}

Kali pertama geran Arus Perdana diperolehi oleh kumpulan yang diketuai oleh Zakaria Stapa melalui geran Arus Perdana siri kedua yang menjalankan penyelidikan Nilai Keagamaan Masyarakat Melayu dalam Arus Globalisasi. Geran tahun 2000 tersebut berjumlah RM50,000.00. Apabila diperkenalkan kembali Penyelidikan Arus Perdana siri ketiga pada tahun 2009, tujahan-tujahan yang sedia terbina dalam GUP tersebut tidak lagi menjadi keutamaan kerana objektif geran Arus Perdana siri ini lebih kepada mengglobalkan penyelidikan sedia ada ke arah satu payung penyelidikan yang memperkasakan 
kepelbagaian tujahan di Universiti Kebangsaan Malaysia. Di Fakulti Pengajian Islam, penyelidikan Arus Perdana siri ketiga tersebut juga diketuai oleh Zakaria Stapa dengan judul Ilmu Dalam Tamadun Islam: Dalam Perbentukan Jati Diri Bangsa Melayu. Penyelidikan bernilai RM310,000.00 ini lebih bersifat tertutup dan top down. Hal ini telah menyebabkan tiga implikasi negatif kepada pemohon dana penyelidikan di Fakulti Pengajian Islam. Pertama, ia menyebabkan para penyelidik tidak dapat bersaing secara terbuka memohon dana penyelidikan seperti amalan yang dilaksanakan dalam geran GUP. Kedua, amalan top down tersebut juga menyebabkan bilangan penyelidik di Fakulti Pengajian Islam menurun secara mendadak daripada 31 ketua penyelidik dalam GUP pada tahun 2008 kepada 1 ketua penyelidik dalam Penyelidikan Arus Perdana pada tahun 2010. Pemilihan ahli penyelidik pula berdasarkan kepada kecenderungan ketua penyelidik. Ketiga, penekanan kepada cross faculty yang diamalkan dalam Penyelidikan Arus Perdana ini telah menyempitkan ruang penyelidik Fakulti Pengajian Islam untuk menyertai penyelidikan berkenaan. Daripada 8 orang penyelidik, 3 penyelidik terdiri daripada pensyarah luar Fakulti Pengajian Islam.

\section{Geran Penyelidikan Tindakan/Strategik 2009}

Pada tahun 2009, Geran Penyelidikan Tindakan/Strategik telah diperkenalkan oleh pihak Timbalan Naib Canselor (Hal Ehwal Akademik dan Antarabangsa) yang memfokuskan kepada pembelajaran dan pengajaran di Universiti Kebangsaan Malaysia. Ini telah membuka kembali ruang bagi penyelidik Fakulti yang terbatas atas polisi Arus Perdana sebelum ini. Sebanyak 12 geran penyelidikan yang setiap satunya bernilai RM12,000.00 dan berdurasi selama setahun telah diberikan kepada dua belas kumpulan penyelidik Fakulti Pengajian Islam. 4 projek penyelidikan (33.4\%) tersebut diperolehi oleh para penyelidik dari Jabatan Pengajian Dakwah dan Kepimpinan, diikuti 3 projek oleh para penyelidik Jabatan Pengajian al-Quran dan Sunnah, masing-masing 2 projek oleh penyelidik Jabatan Syariah serta Jabatan Pengajian Arab dan Tamadun Islam. Hanya 1 geran penyelidikan diperolehi oleh penyelidik Jabatan Usuluddin dan Falsafah. Jadual 6 di bawah adalah senarai Geran Penyelidikan Tindakan/Strategik 2009 di Fakulti Pengajian Islam:

\begin{tabular}{|c|l|l|}
\hline Bil. & \multicolumn{1}{|c|}{ Ketua Penyelidik } & \multicolumn{1}{c|}{ Tajuk } \\
\hline 1. & Zakaria Stapa & $\begin{array}{l}\text { Aplikasi Strategi Penyelidikan dalam Menrealisasikan Keperluan } \\
\text { Pasaran: Kajian dalam Kalangan Pelajar Pra Siswazah Fakulti } \\
\text { Pengajain Islam }\end{array}$ \\
\hline 2. & Ibnor Azli Ibrahim & $\begin{array}{l}\text { Penstrukturan Semula Jabatan Syariah Sebagai Sebuah Fakulti: Satu } \\
\text { Impak terhadap Ekosistem Akademik UKM dari Sudut Ilmu dan } \\
\text { Komersial }\end{array}$ \\
\hline 3. & Sabri Mohamad & $\begin{array}{l}\text { Sistem Pengajaran dan Pembelajaran Tahfiz dan Ilmu Qiraat di IPT } \\
\text { Selangor }\end{array}$ \\
\hline 4. & Ismail Yusoff & Pengajaran dan Pembelajaran Tafsir di IPT Selangor \\
\hline 5. & Latifah Abdul Majid & Pengajaran dan Pembelajaran Hadith di IPT Selangor \\
\hline 6. & Zaini Nasohah & $\begin{array}{l}\text { Kekuatan dan Kelemahan Aspek Amali dalam Pengajaran Kursus } \\
\text { Program Diploma Pentadbiran Kehakiman dan Guaman Islam UKM }\end{array}$ \\
\hline 7. & Zamri Ariffin & $\begin{array}{l}\text { Kebolehbacaan Teks Sastera Arab dalam Kalangan Pelajar Jabatan } \\
\text { Pengajian Arab dan Tamadun Islam, FPI }\end{array}$ \\
\hline 8. & Idris Abdullah & Al-Balaghah dan Kesannya Terhadap Perkembangan Ilmu Islam \\
\hline 9. & Salasiah Hanin Hamjah & $\begin{array}{l}\text { Kaedah Meningkatkan Motivasi Belajar dalam Kalangan Pelajar } \\
\text { Fakulti Pengajian Islam }\end{array}$ \\
\hline 10. & Abdul Ghafar Don & $\begin{array}{l}\text { Kajian Penilaian Program Khidmat Sosial sebagai Kaedah Amali } \\
\text { Dakwah Non Muslim Jabatan Pengajian Dakwah dan Kepimpinan }\end{array}$ \\
\hline
\end{tabular}




\begin{tabular}{|c|l|l|}
\hline 11. & $\begin{array}{l}\text { Uhmad Redzuwan } \\
\text { Mohd Yunus }\end{array}$ & $\begin{array}{l}\text { Ke Arah Peningkatan Mutu Kursus Pra Penempatan Latihan } \\
\text { Amali/Industri, Fakulti Pengajian Islam di Kalangan Para Pelajar }\end{array}$ \\
\hline 12. Mohd. & $\begin{array}{l}\text { Badlihisham } \\
\text { Nasir }\end{array}$ & $\begin{array}{l}\text { Latihan Amali Dakwah (Muslim), Jabatan Pengajian Dakwah dan } \\
\text { Kepimpinan FPI: Kajian Masalah dan Keberkesanan dan } \\
\text { Perlaksanaannya di Felda Gugusan Tersang, Raub, Pahang }\end{array}$ \\
\hline
\end{tabular}

Jadual 6: Geran Penyelidikan Tindakan/Strategik 2009 Fakulti Pengajian Islam

Jika diteliti kepada aspek permasalahan kajian, didapati empat penyelidikan berkenaan tidak memfokus secara langsung kepada masalah pengajaran dan pembelajaran di Fakulti Pengajian Islam khususnya dan Universiti Kebangsaan Malaysia umumnya. Permasalahan kajian lebih bersifat umum dalam bidang pengajian Islam. Keempat-empat penyelidikan tersebut ialah Sistem Pengajaran dan Pembelajaran Tahfiz dan Ilmu Qiraat di IPT Selangor, Pengajaran dan Pembelajaran Tafsir di IPT Selangor, Pengajaran dan Pembelajaran Hadith di IPT Selangor serta Al-Balaghah dan Kesannya Terhadap Perkembangan Ilmu Islam. Dalam aspek tujahan pula, ketiga-tiga penyelidikan oleh penyelidik Jabatan Pengajian al-Quran dan al-Sunnah tersebut oleh disatukan di bawah satu penyelidikan iaitu hadith, tafsir dan qiraat. Jika dilihat kepada aspek penumpuan, penyelidik Jabatan Pengajian Dakwah dan Kepimpinan lebih menumpukan kepada aspek perkembangan kurikulum berasaskan aktiviti pelajar (student centric) berbanding dengan penyelidikan lain yang lebih memfokuskan kepada kurikulum (curiculum centric).

Manakala pada tahun 2010, bilangan Geran Penyelidikan Tindakan/Strategik di Fakulti Pengajian Islam telah meningkat daripada 12 buah kepada 17 buah penyelidikan. 8 buah penyelidikan setiap satunya memperolehi dana sebanyak RM 5 500.00, manakala selebihnya setiap satunya bernilai RM10,000.00. Namun dari keseluruhan jumlah dana, nilai perolehan dana telah menyusut kepada RM134,000.00 berbanding RM144,000.00 pada tahun sebelumnya. Pada tahun 2010, Unit Bahasa Arab Fakulti Pengajian Islam turut memperolehi 4 buah penyelidikan bernilai RM40,000.00 dan sebuah penyelidikan bernilai RM5,500.00 diberikan kepada Pusat Tanggungjawab (PTJ) Fakulti Pengajian Islam. Namun tiada sebarang geran diberikan kepada para penyelidik Jabatan Syariah pada tahun ini berbanding sebuah penyelidikan pada tahun 2009. Jadual 7 berikut adalah senarai Geran Penyelidikan Tindakan/Strategik 2010 di Fakulti Pengajian Islam:

\begin{tabular}{|c|l|l|}
\hline Bil. & \multicolumn{1}{|c|}{ Ketua Penyelidik } & \multicolumn{1}{c|}{ Tajuk } \\
\hline 1. & Fadlan Mohd Othman & $\begin{array}{l}\text { Aplikasi Takhrij Hadith terhadap Disertasi Sarjana di Fakulti } \\
\text { Pengajian Islam dari Tahun 2007 hingga 2009 }\end{array}$ \\
\hline 2. & Salasiah Hanin Hamjah & $\begin{array}{l}\text { Strategi Peningkatan Motivasi Kerja dalam Kalangan } \\
\text { Pensyarah: Satu Kajian di Fakulti Pengajian Islam, UKM }\end{array}$ \\
\hline 3. & Zamri Ariffin & $\begin{array}{l}\text { Penilaian Semula Modul Kursus Bahasa Arab Fakulti Pengajian } \\
\text { Islam, Program Eksekutif dan Program Pengajian Berterusan } \\
\text { di Pusat Kembangan Pendidikan (PKP), UKM }\end{array}$ \\
\hline 4. & Salmah Ahmad & $\begin{array}{l}\text { Perlaksanaan Reader's Theatre dalam Kursus Bahasa Arab: } \\
\text { Penambahbaikan dan Buku Panduan Praktikal }\end{array}$ \\
\hline 5. & $\begin{array}{l}\text { Ahmad Redzuwan Mohd Kajan } \\
\text { Yunus }\end{array}$ & $\begin{array}{l}\text { Keberkesanan Pembelajaran dan Pengajaran Kursus Kajan } \\
\text { Budaya Etnik Malaysia }\end{array}$ \\
\hline 6. & Moktar Hussain & $\begin{array}{l}\text { Pembangunan Laman Sesawang Kemahiran Mendengar } \\
\text { Bahasa Arab (Maharat Istima' al-Fahm): Mendokong Dasar E- } \\
\text { Pembelajaran di UKM } \\
\text { Program Pengajian Siswazah Fakulti Pengajian Islam: Persepsi }\end{array}$ \\
\hline 7. & Mohd. Nasir Omar & \multicolumn{2}{|c}{}
\end{tabular}




\begin{tabular}{|c|l|l|}
\hline & & Pelajar Siswazah terhadap Prosedur dan Pelaksanaan \\
\hline 8. & Zainuddin Ismail & $\begin{array}{l}\text { Bagaimana Kami Menjana Kecenderungan Pelajar untuk } \\
\text { Bertutur dalam Bahasa Arab Sesama Mereka }\end{array}$ \\
\hline 9. & $\begin{array}{l}\text { Azmul Fahimi } \\
\text { Kamaruzaman }\end{array}$ & $\begin{array}{l}\text { Penggunaan Teks Arab Klasik di Kalangan Pelajar dalam } \\
\text { pengajian Sejarah dan tamadun Islam, FPI }\end{array}$ \\
\hline 10. & Faizol Azham Mohamed & $\begin{array}{l}\text { Bagaimana Menggalakkan Para Pelajar Membaca Bahan-bahan } \\
\text { dalam Bahasa Arab dengan Lebih Kerap dan Efektif }\end{array}$ \\
\hline 11. & $\begin{array}{l}\text { Ahmad Fakhrurazi Mohamed } \\
\text { Zabidi }\end{array}$ & $\begin{array}{l}\text { Penggubalan Aktiviti Ko Kurikulum Berimpak Keusahawanan } \\
\text { yang Berteraskan Pengajian Islam }\end{array}$ \\
\hline 12. & Kaseh Abu Bakar & $\begin{array}{l}\text { Ujian Kelayakan Bahasa Arab Siswazah: Analisa Item dan } \\
\text { Pewujudan Bank Item }\end{array}$ \\
\hline 13. & Badlihisham Mohd Nasir & $\begin{array}{l}\text { Keberkesanan Praktikum Latihan Amali/Industri Fakulti } \\
\text { Pengajian Islam di Kalangan Pelajar }\end{array}$ \\
\hline 14. & Jaffary Awang & $\begin{array}{l}\text { Kursus Perbandingan Agama dan Impaknya terhadap } \\
\text { Perbentukan Sikap Toleransi Beragama di Kalangan Pelajar } \\
\text { Jabatan Usuluddin dan Falsafah }\end{array}$ \\
\hline 15. & $\begin{array}{l}\text { Wan Fariza Alyati Wan } \\
\text { Zakaria }\end{array}$ & $\begin{array}{l}\text { Bagaimana untuk Meningkatkan Minat Pelajar terhadap } \\
\text { Kursus PH 1153 Pengantar Falsafah }\end{array}$ \\
\hline 16. & $\begin{array}{l}\text { Al Muslim Mustapa @ Ab } \\
\text { Rahim }\end{array}$ & $\begin{array}{l}\text { Peningkatan Kemahiran Bahasa Arab melalui Modul } \\
\text { Permainan Bahasa }\end{array}$ \\
\hline 17. & Hakim bin Zainal & $\begin{array}{l}\text { Penilaian dan Penambahbaikan Sistem Penilaian Subjek PZ } \\
6013 \text { bahasa Arab Pengukuhan I di Jabatan Pengajian Arab dan } \\
\text { Tamadun Islam, FPI, UKM }\end{array}$ \\
\hline
\end{tabular}

Jadual 7: Geran Penyelidikan Tindakan/Strategik 2010 Fakulti Pengajian Islam

Sepanjang empat dekad penubuhan Fakulti Pengajian Islam, kuantiti dan jumlah geran penyelidikan sama ada dari dalam atau luar UKM semakin meningkat. Peningkatan ini seiring dengan pencapaian usia 40 tahun Universiti Kebangsaan terutama setelah diangkat sebagai universiti penyelidikan pada tahun 2007. Antara pencapaian terbaik, apabila Penyelidikan Sistem Pakar Khidmat Nasihat Kekeluargaan Islam: Pendekatan \& Implementasi yang diketuai oleh Jawiah Dakir berjaya memenangi Gold Medal pada Pameran R\&D Institut Pengajian Tinggi Awam (IPTA) di Putera World Trade Centre, Kuala Lumpur pada 30 September hingga 2 Oktober 2005. Walaupun tidak memenangi pingat, sekurangkurangnya penyelidikan tersebut diangkat pada peringkat antarabangsa apabila ia dipertandingkan di International Exhibition of Invention New Techniques and Products, Geneva, Switzerland pada 5-9 April 2006. Demikian juga dengan pencapaian 4 geran IRPA, 21 geran FRGS dan 7 geran agensi luar UKM.

Namun demikian, sepanjang empat dekad tersebut juga, beberapa kelemahan berkaitan dengan penyelidikan di Fakulti Pengajian Islam dikenalpasti. Jika dilihat kepada jumlah penyelidikan, didapati hanya terdapat 82 buah penyelidikan yang memperolehi geran penyelidikan sepanjang 40 tahun penubuhan Fakulti Pengajian Islam. Ini bermakna hanya 2 penyelidikan setahun dilaksanakan di Fakulti Pengajian Islam. Jika dilihat kepada nisbah pensyarah (108 orang pada tahun 2010) berbanding dengan penyelidikan (82), bermakna seramai 27 orang pensyarah belum pernah mengetuai penyelidikan sepanjang tempoh tersebut. Fakta ini tidak mengambil kira penyelidik yang mengetuai lebih daripada satu penyelidikan.

Dari aspek geran pula, belum ada penyelidikan di Fakulti Pengajian Islam yang memperolehi dana penyelidikan luar negara kecuali oleh Ibrahim Abu Bakar melalui Japan Society for Promotion of Science pada tahun 2002. Geran-geran yang diperolehi sepanjang 40 tahun adalah bersifat tempatan dan dianggap mudah diperolehi berbanding geran-geran 
institusi antarabangsa yang lebih sukar dan berprestij. Sepanjang empat dekad, belum ada geran penyelidikan di Fakulti Pengajian Islam mencecah nilai setengah juta ringgit. Hanya penyelidikan Survival Minoriti Etnik Melayu Muslim: Kajian Etnografi terhadap Amalan Keagamaan dan Akidah Islam diketuai oleh Ahmad Sunawari Long berjaya memperolehi geran tertinggi iaitu RM370,000.00 dari dana GUP. Namun begitu, kejayaan memperolehi geran IRPA mencecah setengah juta ringgit juga pada tahun 2004 dan 2005, menjadi detik bersejarah penyelidikan di Fakulti Pengajian Islam kerana sebelum tahun 2004, memperolehi geran IRPA dianggap sebagai suatu yang mustahil dicapai oleh para penyelidik di Fakulti Pengajian Islam.

Lebih RM 2 juta telah disalurkan untuk membiayai penyelidikan di Fakulti Pengajian Islam sepanjang empat dekad. Namun sepanjang tempoh tersebut, belum lagi sebarang hasil penyelidikan berjaya diterbitkan dalam jurnal berimpak tinggi yang tersenarai dalam Scopus dan ISI. Demikian juga timbul persoalan sejauh manakah penyelidikan-penyelidikan tersebut bermanfaat untuk proses pengajaran dan pembelajaran di peringkat Fakulti. Manakala konsep malim dalam bidang penyelidikan di Fakulti Pengajian Islam belum berfungsi sebaik mungkin di mana pensyarah senior belum menunjukkan peranannya sebagai payung kepada pensyarah junior menjadi penyelidik terbaik. Hasil program kolaborasi ke luar negara melalui geran OUP (Operasi Universiti Penyelidikan) berjumlah RM357,500.00 juga belum menampakkan sebarang bentuk kolaborasi penyelidikan di Fakulti Pengajian Islam. Perubahan paradigma para penyelidik di Fakulti Pengajian Islam daripada penyelidikan bersifat kualitatif kepada penyelidik kuantitatif perlu diperbanyakkan dengan penguasaam kemahiran metodologi penyelidikan. Walau bagaimanapun tidak dapat dinafikan, hasil penyelidikan Fakulti Pengajian Islam memberikan impak kepada dasar negara berdasarkan kepada keperluan pemberi dana luar seperti JAKIM dan Kementerian Pelajaran Malaysia.

\section{References}

Fakulti Pengajian Islam. 1998. Audit Akademik Fakulti Pengajian Islam 1998. Bangi : Fakulti Pengajian Islam.

Second Annual Report 1971-1972 Universiti Kebangsaan Malaysia. Bangi : Universiti Kebangsaan Malaysia.

Laporan Tahunan Pertama Universiti Kebangsaan Malaysia 1970-1971. Bangi : Universiti Kebangsaan Malaysia.

Ministry of Science, Technology and the Environment. t.th. Users' Manual for IRPA Programme $8^{\text {th }}$ Malaysia Plan. Jil. 1.

http://jpt.mohe.gov.my/menupenyelidik.php.dg 